\title{
Co-evolution of phytoplankton C:N:P stoichiometry and the deep ocean N:P ratio*
}

Co-evolution of phytoplankton and ocean $\mathrm{N}: \mathrm{P}$ ratios

T. M. Lenton and

C. A. Klausmeier

T. M. Lenton ${ }^{1}$ and C. A. Klausmeier ${ }^{2}$

${ }^{1}$ School of Environmental Sciences, University of East Anglia, Norwich NR4 7TJ, UK

${ }^{2}$ W. K. Kellogg Biological Station, Michigan State University, Hickory Corners, MI 49060, USA

Received: 16 June 2006 - Accepted: 4 July 2006 - Published: 17 July 2006

Correspondence to: T. M. Lenton (t.lenton@uea.ac.uk)

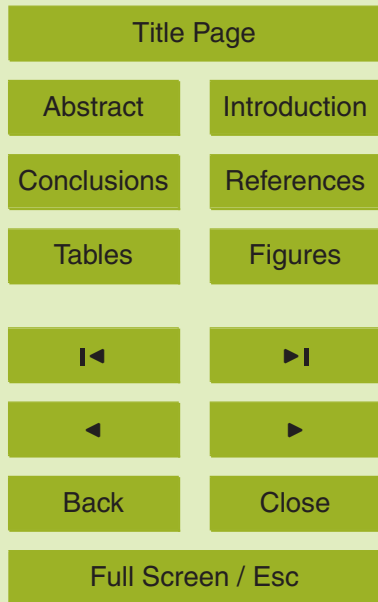

Printer-friendly Version

${ }^{*}$ Invited contribution by T. M. Lenton, one of the EGU Outstanding Young Scientist Award Interactive Discussion winners 2006 


\section{Abstract}

There is a long-established, remarkable correspondence between the nitrogen-tophosphorus ratio N:P 15 of deep ocean water and the "Redfield ratio" of N:P 16 required by phytoplankton. Redfield and subsequent workers have suggested that it is 5 due to $\mathrm{N}$-fixing organisms being selected when $\mathrm{N}: \mathrm{P}<16$ but being out-competed when $\mathrm{N}: \mathrm{P}>16$. Models have shown this mechanism can work, but recent observations reveal that the real system is more complex. First, the C:N:P stoichiometry of phytoplankton varies with growth rate, nutrient and light limitation, species and phylum. Second, although $\mathrm{N}$-fixation is sometimes $\mathrm{P}$-limited and suppressed by $\mathrm{N}$-addition, there is also evidence for Fe-limitation, light-limitation and $\mathrm{P}$ and Fe co-limitation of $\mathrm{N}$-fixers. Here we adapt recent models to include non-Redfieldian stoichiometry of phytoplankton and limitation of $\mathrm{N}$-fixers by resources other than $\mathrm{P}$. We show that the deep ocean $\mathrm{N}: \mathrm{P}$ is set by the $N: P$ threshold that triggers $N$-fixation, and is not directly related to the $N: P$ ratio of sinking material. However, assuming competitive dynamics set the $N: P$ threshold for $\mathrm{N}$-fixation, it will be close to the $\mathrm{N}: \mathrm{P}$ requirement of non-fixers (rather than that of $\mathrm{N}$-fixers) and consequently so will the deep ocean N:P ratio. Theoretical limits on the $\mathrm{N}: \mathrm{P}$ requirements of phytoplankton suggest that since the deep ocean became well oxygenated, its $N: P$ has remained within the range 7.7-32.3. Decreases in phytoplankton $\mathrm{C}: \mathrm{P}$ and $\mathrm{N}: \mathrm{P}$ ratios over the past $\sim 1$ Gyr are predicted to have driven a decrease in deep ocean $\mathrm{N}: \mathrm{P}$, probably via increasing $\mathrm{PO}_{4}$. Even if Fe or light limitation restrict $\mathrm{N}$-fixers to a fraction of the surface ocean, they reach higher densities there, minimising variations in deep ocean N:P. Thus Redfield's mechanism is robust and we expand it to suggest that phytoplankton C:N:P and deep ocean N:P have co-evolved.

\section{Introduction}

25 There is a well-known correspondence between the average proportions of $\mathrm{N}$ and $\mathrm{P}$ in marine organic matter - the "Redfield ratio" of N:P 16 - and the composition of the
BGD

3, 1023-1047, 2006

Co-evolution of phytoplankton and ocean N:P ratios

T. M. Lenton and

C. A. Klausmeier

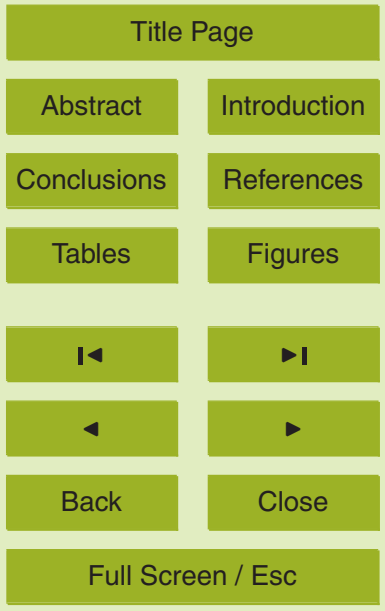

Printer-friendly Version

Interactive Discussion 
deep ocean with $\mathrm{N}: \mathrm{P} \sim 15$. Redfield (1934) suggested that an explanation “... may be sought in the activities of those bacteria which form nitrogenous compounds or liberate nitrogen in the course of the decomposition of organic matter" intuiting that "... in a world populated by organisms of these two types the relative proportion of phosphate 5 and nitrate must tend to approach that characteristic of protoplasm in general..." In his later work, Redfield (1958) proposed that: "When living in an environment containing a deficiency of nitrate relative to phosphate, the growth and assimilation of the nitrogen-fixing organisms might tend continually to bring the proportions of nitrogen and phosphorus nearer to that characteristic of their own substance." Subsequent workers 10 (Broecker and Peng, 1982; Tyrrell, 1999; Lenton and Watson, 2000) have expressed the mechanism in terms of competition between $\mathrm{N}$-fixing organisms that are selected when $\mathrm{N}: \mathrm{P}<16$ and non-fixers that out-compete them when $\mathrm{N}: \mathrm{P}>16$. This mechanism assumes that under $\mathrm{P}$-limiting conditions $\mathrm{N}$-fixers have a lower growth rate than nonfixers, because of the high energy cost of $\mathrm{N}$-fixation, whilst under sufficiently $\mathrm{N}$-limiting conditions $\mathrm{N}$-fixers have a higher growth rate than non-fixers.

The canonical value of $\sim 16$ for the N:P Redfield ratio represents an average for today's phytoplankton. It has long been known that the Redfield ratios of phytoplankton vary with growth rate (Goldman et al., 1979) and light regime (Goldman, 1986). Nutrient replete phytoplankton cultures (with consequently high growth rates) have a mean $\mathrm{N}: \mathrm{P}$ of 10.1 across 34 studies, in contrast to marine particulate matter with a mean $\mathrm{N}: \mathrm{P}$ of 16.4 across 27 studies (Geider and La Roche, 2002). It was thought that N:P 16 might represent some kind of optimum for phytoplankton, but no theoretical basis has been found for this (Klausmeier et al., 2004). Instead, the optimum composition of phytoplankton predicted under exponential growth is 8.2, whilst under light limitation it 25 is 35.8 , nitrogen limitation 37.4 , and phosphorus limitation 45.0. Furthermore, different phyla or super-families of differing antiquity have different N:P, with older "greens" having higher N:P than younger "reds" (Quigg et al., 2003). This raises the question (Falkowski and Davis, 2004; Arrigo, 2005): Would a systematic shift in the Redfield ratios alter deep ocean composition? We address this question by generalising two ex-

BGD

3, 1023-1047, 2006

Co-evolution of phytoplankton and ocean $\mathrm{N}: \mathrm{P}$ ratios

T. M. Lenton and

C. A. Klausmeier

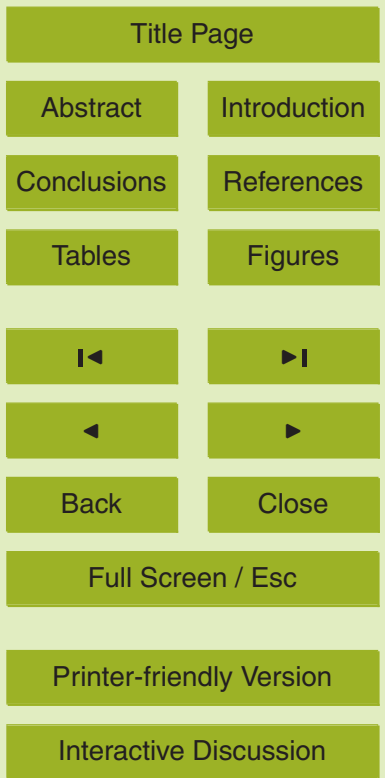

EGU 
isting models (Tyrrell, 1999; Lenton and Watson, 2000) to allow variation of the Redfield ratios.

The question provokes a deeper one: What sets the deep ocean N:P ratio? Some authors still make statements, which can be traced back to Redfield (1934), to the 5 effect that the ratio of major nutrients $N: P \sim 15$ in the deep ocean directly reflects the average Redfield ratio (N:P 16) of sinking organic matter being remineralised in the water column. Whilst the gradient $(\sim 15)$ of a plot of ocean $\mathrm{NO}_{3}$ versus $\mathrm{PO}_{4}$ measurements reflects the ratio in which $\mathrm{N}$ and $\mathrm{P}$ are remineralised, where the line of points intercepts an axis - typically at the origin or close to it, at a low value of $\mathrm{PO}_{4}$ - demands 10 a different explanation. This is because the cycle of uptake in the surface ocean and remineralisation at depth redistributes $\mathrm{NO}_{3}$ and $\mathrm{PO}_{4}$, but cannot alter their absolute or relative amounts in the ocean as a whole, which depend on net input to or removal from the ocean. The ocean mixing time $\left(<10^{3} \mathrm{yr}\right)$ is shorter than the residence time of $\mathrm{NO}_{3}\left(\sim 3 \times 10^{3} \mathrm{yr}\right)$ (Codispoti, 1995; Lenton and Watson, 2000), which is in turn shorter 15 than that of $\mathrm{PO}_{4}\left(\sim 1.8 \times 10^{4} \mathrm{yr}\right)$ (Ruttenberg, 1993; Lenton and Watson, 2000). Hence mixing tends to homogenize the processes setting the concentrations of both nutrients. Furthermore, we can consider a timescale over which $\mathrm{PO}_{4}$ is relatively constant but $\mathrm{NO}_{3}$ can vary due to imbalances of input (primarily $\mathrm{N}$-fixation) and output (primarily denitrification) processes. The essence of Redfield's mechanism is that one of these processes $-\mathrm{N}$-fixation - responds to any deficit of $\mathrm{NO}_{3}$ relative to the $\mathrm{N}: \mathrm{P}$ requirement of average phytoplankton (non-fixers), whilst the other process - denitrification - tends to continually remove $\mathrm{NO}_{3}$ and thus maintain a small $\mathrm{N}: P$ deficit and corresponding population of $\mathrm{N}$-fixers.

Recent discoveries have the potential to further complicate Redfield's mechanism: Although $\mathrm{N}$-fixation is sometimes P-limited and suppressed by $\mathrm{N}$-addition, there is also evidence for Fe-limitation (Berman-Frank et al., 2001; Mills et al., 2004), light-limitation (Hood et al., 2004) and $\mathrm{P}$ and Fe co-limitation (Mills et al., 2004) of $\mathrm{N}$-fixers. This raises the question: Given that $\mathrm{N}$-fixers may be limited to restricted areas of the world ocean, can they still regulate deep ocean N:P? We address this question by adapting one of

\section{Co-evolution of phytoplankton and ocean $\mathrm{N}: \mathrm{P}$ ratios}

T. M. Lenton and

C. A. Klausmeier

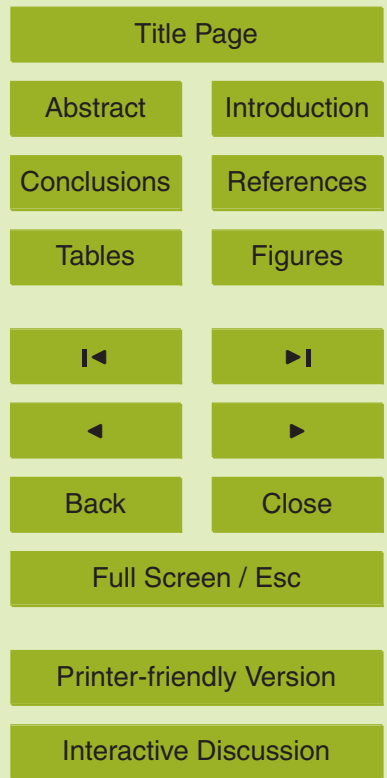

EGU 
the existing models (Tyrrell, 1999) to restrict $\mathrm{N}$-fixers to a fraction of the surface ocean.

\section{Methods}

Here we briefly describe the two models adapted for this study. For full explanations of their formulation see Lenton and Watson (2000) and Tyrrell (1999).

\section{$5 \quad 2.1$ LW model}

Lenton and Watson (2000) (henceforth LW) model deep ocean reservoirs of nitrate (actually available nitrogen) and phosphate, and a reservoir of atmospheric oxygen expressed as the concentration in water ventilating the deep ocean. The limiting nutrient in water up-welled to the surface ocean is assumed to be completely used up, generating a corresponding concentration of new production ( $C$ here instead of $N$, to avoid confusion with Tyrrell's $N$ ):

$C=\min \left(r_{\mathrm{C}: \mathrm{N}} \mathrm{NO}_{3}, \mathrm{r}_{\mathrm{C}: \mathrm{P}} \mathrm{PO}_{4}\right)$

Here we generalize the original model (M1) of LW to allow independent variation of the $\mathrm{C}: \mathrm{N}$ and $\mathrm{C}: \mathrm{P}$ Redfield ratios of new production (sinking organic matter from the surface 15 layer), denoted $r_{\mathrm{C}: \mathrm{N}}$ and $r_{\mathrm{C}: \mathrm{P}}$, and the $\mathrm{N}: \mathrm{P}$ threshold below which $\mathrm{N}$-fixation occurs, denoted $r_{\mathrm{N}: \mathrm{P}, \mathrm{Fix}}$. The generalized equation for $\mathrm{N}$-fixation $\left(F_{\mathrm{N}-\mathrm{Fix}}\right)$ is:

$F_{\mathrm{N}-\mathrm{Fix}}=\frac{k_{3}}{k_{P}}\left(\mathrm{PO}_{4}-\frac{\mathrm{NO}_{3}}{r_{\mathrm{N}: \mathrm{P}, \mathrm{Fix}}}\right)$

All constants are retained including the initial $\mathrm{N}$-fixation flux $k_{3}=8.7 \times 10^{12} \mathrm{~mol} \mathrm{~N} \mathrm{yr}^{-1}$ and the initial normalizing values: the average deep ocean nutrient concentrations of $\mathrm{PO}_{4(0)}=2.2 \mu \mathrm{mol} \mathrm{kg}{ }^{-1}$ and $\mathrm{NO}_{3(0)}=30.9 \mu \mathrm{mol} \mathrm{kg}{ }^{-1}$ from World Ocean Atlas data, a representative oxygen concentration of $\mathrm{O}_{2(0)}=331.5 \mu \mathrm{mol} \mathrm{kg}^{-1}$ for water ventilating the deep ocean, and an average carbon concentration of new production in surface waters

Co-evolution of phytoplankton and ocean $\mathrm{N}$ : $\mathrm{P}$ ratios

T. M. Lenton and C. A. Klausmeier

\section{Title Page}

Abstract Introduction

Conclusions

Tables References Figures

14

$\triangleleft$

Back

Full Screen / Esc

Printer-friendly Version

Interactive Discussion

EGU 
of $C_{0}=226.0 \mu \mathrm{mol} \mathrm{kg}{ }^{-1}$. The derived constant $k_{P}=\mathrm{PO}_{4(0)}-\mathrm{NO}_{3(0)} / 16=0.26875 \mu \mathrm{mol}$ $\mathrm{kg}^{-1}$ represents the surplus $\mathrm{PO}_{4}$ remaining in surface waters after $\mathrm{NO}_{3}$ has been removed by new production. Denitrification in the water column depends on the anoxic fraction of the ocean, $A$, which is given by:

${ }_{5} A=1-k_{1} \frac{\mathrm{O}_{2}}{\mathrm{O}_{2(0)}} \frac{C_{0}}{C}$

where the initial oxic fraction, $k_{1}=0.86$, hence the initial anoxic fraction $A_{0}=0.14$.

For the nitrate reservoir, $\mathrm{N}$-fixation in the surface ocean is balanced by water column denitrification (initially $k_{4}=4.3 \times 10^{12} \mathrm{~mol} \mathrm{~N} \mathrm{yr}^{-1}$ ), a fixed flux of sedimentary denitrification $\left(k_{4}\right)$, and organic nitrogen burial in sediments (initially $0.1 \times 10^{12} \mathrm{~mol} \mathrm{~N} \mathrm{yr}^{-1}$ ):

${ }_{10} \frac{d \mathrm{NO}_{3}}{d t}=k_{8}\left(\frac{k_{3}}{k_{\mathrm{P}}}\left(\mathrm{PO}_{4}-\frac{\mathrm{NO}_{3}}{\mathrm{r}_{\mathrm{N}: \mathrm{P}, \mathrm{Fix}}}\right)-k_{4} \frac{A}{A_{0}}-k_{4}-\frac{k_{2}}{b_{\mathrm{C}: \mathrm{N}}}\left(\frac{C}{C_{0}}\right)^{2}\right)$

where $k_{8}=7.1 \times 10^{-22} \mathrm{~kg}^{-1}$ converts from reservoir size in mol to average concentration, the initial organic carbon burial flux $k_{2}=3.75 \times 10^{12} \mathrm{~mol} \mathrm{C} \mathrm{yr}^{-1}$ and the C: $\mathrm{N}$ burial ratio $b_{\mathrm{C}: \mathrm{N}}=37.5$.

Input to the phosphate reservoir comes from weathering (initially $k_{5}=3.6 \times 10^{10} \mathrm{~mol}$

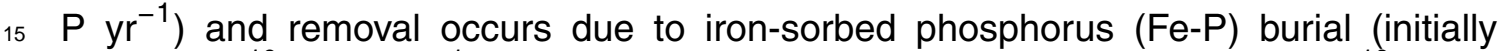
$k_{6}=0.6 \times 10^{10} \mathrm{~mol} \mathrm{P} \mathrm{yr}^{-1}$ ), organic phosphorus (Org- $\mathrm{P}$ ) burial (initially $1.5 \times 10^{10} \mathrm{~mol} \mathrm{P}$ $\mathrm{yr}^{-1}$ ) and calcium-bound phosphorus $(\mathrm{Ca}-\mathrm{P})$ burial (initially $k_{7}=1.5 \times 10^{10} \mathrm{~mol} \mathrm{P} \mathrm{yr}^{-1}$ ):

$\frac{d \mathrm{PO}_{4}}{d t}=k_{8}\left(k_{5} W-\frac{k_{6}}{k_{1}}(1-A)-\frac{k_{2}}{b_{\mathrm{C}: \mathrm{P}}}\left(\frac{C}{C_{0}}\right)^{2}-k_{7}\left(\frac{C}{C_{0}}\right)^{2}\right)$

where $W$ is a normalised weathering forcing parameter (i.e. $W=1$ at present day), and $b_{\mathrm{C}: \mathrm{P}}=250$ is the C:P burial ratio.

BGD

3, 1023-1047, 2006

Co-evolution of phytoplankton and ocean N:P ratios

T. M. Lenton and

C. A. Klausmeier

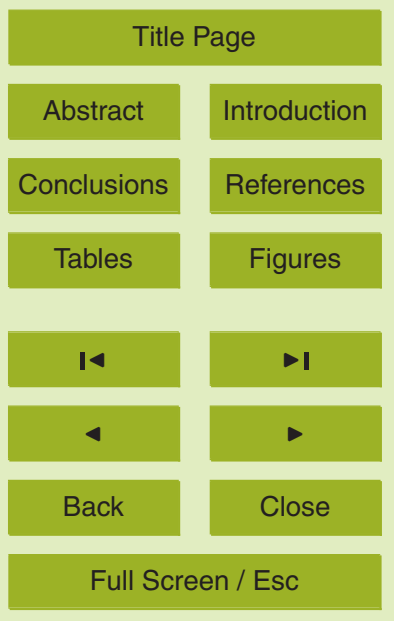

Printer-friendly Version

Interactive Discussion 
Net addition of oxygen occurs due to organic carbon (Org-C) burial and net removal due to oxidative weathering:

BGD

$\frac{d \mathrm{O}_{2}}{d t}=k_{9}\left(k_{2}\left(\frac{C}{C_{0}}\right)^{2}-k_{2} W\right)$

where $k_{9}=8.96 \times 10^{-24} \mathrm{~kg}^{-1}$ converts from atmospheric oxygen reservoir size in mol to 5 concentration dissolved in surface waters ventilating the deep ocean.

The system was solved analytically for steady state following the method in the Appendix of LW but for an unknown limiting nutrient, yielding:

$\frac{C}{C_{0}}=W^{\frac{1}{2}}$

$\frac{\mathrm{O}_{2}}{\mathrm{O}_{2(0)}}=W^{\frac{3}{2}}$

$\mathrm{PO}_{4}=\frac{\mathrm{NO}_{3}}{\mathrm{r}_{\mathrm{N}: \mathrm{P}-\mathrm{Fix}}}+\mathrm{k}_{\mathrm{P}}(4.025-3.025 \mathrm{~W})$

$A=1-k_{1} W$

Steady state for $\mathrm{O}_{2}$ is lost when $A \rightarrow 0$, which from Eq. (10) gives an upper limit on $W=1.163$ (above this, $\mathrm{O}_{2}$ increases monotonically).

\subsection{TT model}

15 Tyrrell (1999) (henceforth TT) models nitrate and phosphate in two boxes, the surface and deep ocean, and includes explicit competition between $\mathrm{N}$-fixing and non-fixing organisms in the surface ocean. However, the TT model does not include any cycling of carbon or oxygen, hence the effects of changes in $\mathrm{C}: \mathrm{P}$ and $\mathrm{C}: \mathrm{N}$ Redfield ratios cannot be addressed.

\section{3, 1023-1047, 2006}

Co-evolution of phytoplankton and ocean $\mathrm{N}: \mathrm{P}$ ratios

T. M. Lenton and

C. A. Klausmeier

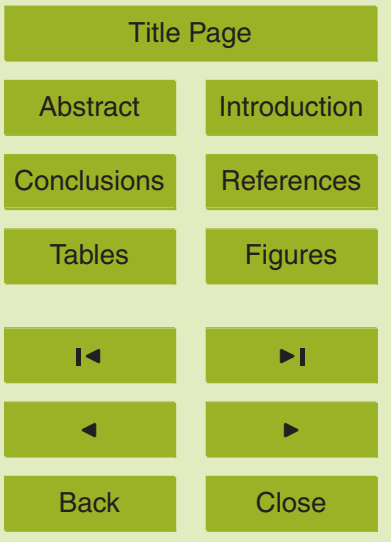

Full Screen / Esc

Printer-friendly Version

Interactive Discussion 
We extended the TT model in two ways. First, nitrogen-fixers and other phytoplankton are given different $\mathrm{N}: \mathrm{P}$ stoichiometry $\left(R_{N F}\right.$ and $R_{O}$ respectively). Second, the surface layer of the ocean is split into a fraction where nitrogen-fixers can grow $\left(f_{A}\right)$ and a fraction where they cannot $\left(f_{B}=1-f_{A}\right)$, due to light, iron, or temperature5 limitation. These two parts are not directly coupled, but both exchange nutrients and dead biomass with the deep layer. The subscripts $A, B$ and $D$ refer to the two surface boxes and the deep box, respectively. $N F$ is the standing stock of $\mathrm{N}$-fixers and $O$ that of other phytoplankton. $P$ and $N$ are the concentrations of $\mathrm{PO}_{4}$ and $\mathrm{NO}_{3}$, respectively. All other symbols and parameter values are as in Tyrrell (1999).

10 The population dynamics are described by:

$\frac{d N F_{A}}{d t}=\mu_{N F}^{\prime} \cdot \frac{P_{A}}{P_{A}+P_{H}} \cdot N F_{A}-M \cdot N F_{A}$

$\frac{d O_{A}}{d t}=\mu_{O}^{\prime} \cdot \min \left(\frac{P_{A}}{P_{A}+P_{H}}, \frac{N_{A}}{N_{A}+N_{H}}\right) \cdot O_{A}-M \cdot O_{A}$

$\frac{d O_{B}}{d t}=\mu_{O}^{\prime} \cdot \min \left(\frac{P_{B}}{P_{B}+P_{H}}, \frac{N_{B}}{N_{B}+N_{H}}\right) \cdot O_{B}-M \cdot O_{B}$

where $P_{H}=3 \times 10^{-5} \mathrm{~mol} \mathrm{P} \mathrm{m}^{-3}$ and $N_{H}=5 \times 10^{-4} \mathrm{~mol} \mathrm{~N} \mathrm{~m}^{-3}$ are half-saturation constants 15 for growth on $\mathrm{PO}_{4}$ and $\mathrm{NO}_{3}$ respectively, $\mu_{N F}^{\prime}=87.6 \mathrm{yr}^{-1}$ and $\mu_{O}^{\prime}=91.25 \mathrm{yr}^{-1}$ are maximum growth rates for $\mathrm{N}$-fixers and other phytoplankton respectively, and $M=73 \mathrm{yr}^{-1}$ is mortality.

Nutrient concentrations in the surface ocean boxes are described by:

$$
\begin{aligned}
& \frac{d P_{A}}{d t}=-\mu_{N F}^{\prime} \cdot \frac{P_{A}}{P_{A}+P_{H}} \cdot \frac{N F_{A}}{R_{N F}}-\mu_{O}^{\prime} \cdot \min \left(\frac{P_{A}}{P_{A}+P_{H}}, \frac{N_{A}}{N_{A}+N_{H}}\right) \cdot \frac{O_{A}}{R_{O}}+M \cdot S R \cdot \frac{N F_{A}}{R_{N F}} \\
&+M \cdot S R \cdot \frac{O_{A}}{R_{O}}+\frac{K \cdot\left(P_{D}-P_{A}\right)}{S D}+\frac{R P}{S D} \\
& \frac{d N_{A}}{d t}=-\mu_{O}^{\prime} \cdot \min \left(\frac{P_{A}}{P_{A}+P_{H}}, \frac{N_{A}}{N_{A}+N_{H}}\right) \cdot O_{A}+M \cdot(S R-0.75 \cdot D N) \cdot N F_{A} \\
&+M \cdot(S R-0.75 \cdot D N) \cdot O_{A}+\frac{K \cdot\left(N_{D}-N_{A}\right)}{S D}+\frac{(R N+A N)}{S D} \\
& 1030
\end{aligned}
$$

\section{BGD}

3, 1023-1047, 2006

Co-evolution of phytoplankton and ocean $\mathrm{N}: \mathrm{P}$ ratios

T. M. Lenton and C. A. Klausmeier

\section{Title Page}

Abstract Introduction

Conclusions

Tables

References

Figures

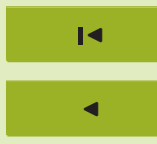

Back

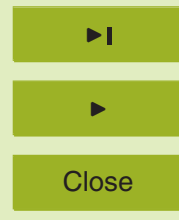

Full Screen / Esc

Printer-friendly Version

Interactive Discussion 
$\frac{d P_{B}}{d t}=-\mu_{O}^{\prime} \cdot \min \left(\frac{P_{B}}{P_{B}+P_{H}}, \frac{N_{B}}{N_{B}+N_{H}}\right) \cdot \frac{O_{B}}{R_{O}}+M \cdot S R \cdot \frac{O_{B}}{R_{O}}+\frac{K \cdot\left(P_{D}-P_{B}\right)}{S D}+\frac{R P}{S D}$

$$
\begin{aligned}
\frac{d N_{B}}{d t} & =-\mu_{O}^{\prime} \cdot \min \left(\frac{P_{B}}{P_{B}+P_{H}}, \frac{N_{B}}{N_{B}+N_{H}}\right) \cdot O_{B}+M \cdot(S R-0.75 \cdot D N) \cdot O_{B} \\
& +\frac{K \cdot\left(N_{D}-N_{B}\right)}{S D}+\frac{(R N+A N)}{S D}
\end{aligned}
$$

where $S D=500 \mathrm{~m}$ is the depth of the surface layer, $S R=95 \%$ is the fraction of total primary productivity regenerated in the surface layer, and $K=3.0 \mathrm{~m} \mathrm{yr}^{-1}$ is the mixing 5 coefficient between the surface and the deep. $R P=2.0 \times 10^{-4} \mathrm{~mol} \mathrm{P} \mathrm{m}^{-2} \mathrm{yr}^{-1}$ is the river input of $\mathrm{P}$. $R N=6.0 \times 10^{-3} \mathrm{~mol} \mathrm{~N} \mathrm{~m}^{-2} \mathrm{yr}^{-1}$ is the river input of $\mathrm{N}, A N=7.5 \times 10^{-3} \mathrm{~mol} \mathrm{~N}$ $\mathrm{m}^{-2} \mathrm{yr}^{-1}$ is the atmospheric input of $\mathrm{N}, D N=1.5 \%$ is the fraction of total $\mathrm{N}$ uptake that is converted to $\mathrm{N}_{2}$ via denitrification.

Deep ocean nutrient concentrations are given by:

$$
\begin{aligned}
\frac{d P_{D}}{d t} & =M \cdot D R \cdot \frac{N F_{A}}{R_{N F}} \cdot \frac{f_{A} \cdot S D}{D D}+M \cdot D R \cdot \frac{O_{A}}{R_{O}} \cdot \frac{f_{A} \cdot S D}{D D}+M \cdot D R \cdot \frac{O_{B}}{R_{O}} \cdot \frac{f_{B} \cdot S D}{D D} \\
& -\frac{K \cdot\left(P_{D}-f_{A} P_{A}-f_{B} P_{B}\right)}{D D} \\
\frac{d N_{D}}{d t} & =M \cdot(D R-0.25 \cdot D N) \cdot N F_{A} \cdot \frac{f_{A} \cdot S D}{D D}+M \cdot(D R-0.25 D N) \cdot O_{A} \cdot \frac{f_{A} \cdot S D}{D D} \\
& +M \cdot(D R-0.25 D N) \cdot O_{B} \cdot \frac{K B}{D D}-\frac{K \cdot\left(N_{D}-f_{A} N_{A}-f_{B} N_{B}\right)}{D D}
\end{aligned}
$$

where $D D=3230 \mathrm{~m}$ is the depth of the deep layer, and $D R=4.8 \%$ is the fraction of total primary productivity regenerated in the deep layer (leaving $0.2 \%$ to be permanently incorporated into sediments).

15 Setting $f_{A}=1$ and $R_{N F}=R_{O}=16$ ( $=R_{\mathrm{ORG}}$ ) recovers the original TT model. These equations were solved numerically with a Fortran program and using Mathematica software.

\section{BGD}

3, 1023-1047, 2006

Co-evolution of phytoplankton and ocean $\mathrm{N}$ :P ratios

T. M. Lenton and C. A. Klausmeier

\section{Title Page}

Abstract Introduction

Conclusions

Tables

References

Figures

14

4

Back

Close

Full Screen / Esc

Printer-friendly Version

Interactive Discussion 


\section{Results}

\subsection{What controls deep ocean N:P?}

BGD

From the analytical solution of the LW model for steady state (Sect. 2.1), rearranging Eq. (9), we find the following relationship between available nitrogen $\left(\mathrm{NO}_{3}\right)$ and phos5 phorus $\left(\mathrm{PO}_{4}\right)$ in the deep ocean (valid for normalised weathering forcing $0 \leq W \leq 1.163$ ):

$\frac{\mathrm{NO}_{3}}{\mathrm{PO}_{4}}=r_{\mathrm{N}: \mathrm{P}, \mathrm{Fix}}\left(1-\frac{k_{P}(4.025-3.025 W)}{\mathrm{PO}_{4}}\right)$

For close to present day weathering $W \sim 1$, deep ocean $\mathrm{N}: \mathrm{P}$ is set slightly below the $\mathrm{N}: \mathrm{P}$ threshold that triggers $\mathrm{N}$-fixation $\left(r_{\mathrm{N}: \mathrm{P}, \mathrm{Fix}}\right)$, because $k_{P}=0.26875 \mu \mathrm{mol} \mathrm{kg}^{-1}$ is small. Denitrification in the water column and sediments, plus a small amount of organic ni10 trogen burial, continually remove $\mathrm{N}$ from the ocean, thus lowering $\mathrm{N}: \mathrm{P}$ and supporting a counter-balancing flux of $\mathrm{N}$-fixation. Decreasing weathering increases the deficit of deep ocean N:P below the threshold triggering $\mathrm{N}$-fixation, whereas increasing weathering (within the limit $W \leq 1.163$ ) reduces the deficit. The actual concentrations of $\mathrm{NO}_{3}$ and $\mathrm{PO}_{4}$, and which limits new production, are determined by $r_{\mathrm{C}: \mathrm{N}}, r_{\mathrm{C}: \mathrm{P}}, r_{\mathrm{N}: \mathrm{P}, \mathrm{Fix}}$, the constraint (20), and the steady state solution for new production $(C)$ in surface waters:

$$
\min \left(r_{\mathrm{C}: \mathrm{N}} \mathrm{NO}_{3}, \mathrm{r}_{\mathrm{C}: \mathrm{P}} \mathrm{PO}_{4}\right)=C_{0} W^{\frac{1}{2}}
$$

If we fix the weathering forcing parameter at $W=1$ (thus making $\mathrm{PO}_{4}$ input to the ocean and $\mathrm{O}_{2}$ removal from the atmosphere constant), then $\mathrm{O}_{2}=\mathrm{O}_{2(0)}, C=C_{0}$ (from Eqs. 7 and 8), the ocean has a constant anoxic fraction, $A=A_{0}=0.14$, and:

${ }_{20} \frac{\mathrm{NO}_{3}}{\mathrm{PO}_{4}}=r_{\mathrm{N}: \mathrm{P}, \mathrm{Fix}}\left(1-\frac{k_{P}}{\mathrm{PO}_{4}}\right)$

$$
\min \left(r_{\mathrm{C}: \mathrm{N}} \mathrm{NO}_{3}, \mathrm{r}_{\mathrm{C}: \mathrm{P}} \mathrm{PO}_{4}\right)=C_{0}
$$

Co-evolution of phytoplankton and ocean $\mathrm{N}: \mathrm{P}$ ratios

T. M. Lenton and C. A. Klausmeier

\section{Title Page}

Abstract Introduction

Conclusions

Tables References Figures

14

4

Back

Close

Full Screen / Esc

Printer-friendly Version

Interactive Discussion 
where $C_{0}=226.0 \mu \mathrm{mol} \mathrm{kg}{ }^{-1}$. Only one of $\mathrm{NO}_{3}=226 / r_{\mathrm{C}: \mathrm{N}}$ and $\mathrm{PO}_{4}=226 / r_{\mathrm{C}: \mathrm{P}}$ as limiting is consistent with the value of the other nutrient calculated from Eq. (22). If $r_{\mathrm{C}: \mathrm{N}} \times r_{\mathrm{N}: \mathrm{P}, \mathrm{Fix}} \leq r_{\mathrm{C}: \mathrm{P}}$ then $\mathrm{NO}_{3}$ must be limiting, if $r_{\mathrm{C}: \mathrm{N}} \times r_{\mathrm{N}: \mathrm{P}, \mathrm{Fix}}>r_{\mathrm{C}: \mathrm{P}}$ then $\mathrm{PO}_{4}$ can be limiting. LW took $r_{\mathrm{C}: \mathrm{N}}=117 / 16=7.3125$ and $r_{\mathrm{C}: \mathrm{P}}=117$ from nutrient data analysis (Anderson

5 and Sarmiento, 1994) and assumed $r_{\mathrm{N}: \mathrm{P}, \mathrm{Fix}}=r_{\mathrm{C}: \mathrm{P}} / r_{\mathrm{C}: \mathrm{N}}=16$, corresponding to a steady state $\mathrm{PO}_{4}=2.2 \mu \mathrm{mol} \mathrm{kg}{ }^{-1}$ and $\mathrm{NO}_{3}=30.9 \mu \mathrm{mol} \mathrm{kg}{ }^{-1}$, i.e. deep ocean $\mathrm{N}: \mathrm{P}=14.0$ (a little below observations).

The $\mathrm{N}: \mathrm{P}$ ratio of the deep ocean tracks changes in the $\mathrm{N}: \mathrm{P}$ threshold for $\mathrm{N}$-fixation (Eqs. 20 and 22). To illustrate this, let us conduct a thought experiment and assume 10 that a systematic shift occurs in phytoplankton stoichiometry to $r_{\mathrm{C}: \mathrm{N}}=7.5$ and $r_{\mathrm{C}: \mathrm{P}}=75$ (i.e. $\mathrm{N}: \mathrm{P}=10$ in new production, based on average values from culture studies; Geider and La Roche, 2002), but there is no change in $r_{\mathrm{N}: \mathrm{P}, \mathrm{Fix}}=16$. In the new steady state, $\mathrm{PO}_{4}=3.0 \mu \mathrm{mol} \mathrm{kg}{ }^{-1}, \mathrm{NO}_{3}=43.7 \mu \mathrm{mol} \mathrm{kg}{ }^{-1}$ i.e. deep ocean $\mathrm{N}: \mathrm{P}=14.6$ has changed very little and $\mathrm{P}$ now limits new production. Conversely, if we arbitrarily assume $r_{\mathrm{N}: \mathrm{P}, \mathrm{Fix}}=10$ 15 but keep the original $r_{\mathrm{C}: \mathrm{N}}=7.3125$ and $r_{\mathrm{C}: \mathrm{P}}=117$ (i.e. $\mathrm{N}: \mathrm{P}=16$ in new production) the new steady state has $\mathrm{PO}_{4}=3.36 \mu \mathrm{mol} \mathrm{kg}{ }^{-1}, \mathrm{NO}_{3}=30.9 \mu \mathrm{mol} \mathrm{kg}{ }^{-1}$, i.e. deep ocean $\mathrm{N}: \mathrm{P}=9.2$ has dropped significantly and $\mathrm{N}$ is extremely limiting to new production. Finally, if we assume $r_{\mathrm{C}: \mathrm{N}}=7.5, r_{\mathrm{C}: \mathrm{P}}=75$ and $r_{\mathrm{N}: \mathrm{P}, \mathrm{Fix}}=r_{\mathrm{C}: \mathrm{P}} / r_{\mathrm{C}: \mathrm{N}}=10$ then, $\mathrm{PO}_{4}=3.28 \mu \mathrm{mol}$ $\mathrm{kg}^{-1}, \mathrm{NO}_{3}=30.1 \mu \mathrm{mol} \mathrm{kg}{ }^{-1}$ i.e. deep ocean $\mathrm{N}: \mathrm{P}=9.2$ and $\mathrm{N}$ limits new production. 20 Thus, a systematic change in phytoplankton C:N:P can alter the concentrations of $\mathrm{NO}_{3}$ and $\mathrm{PO}_{4}$ in the deep ocean but cannot significantly alter their ratio, unless it also alters the $\mathrm{N}: \mathrm{P}$ threshold for $\mathrm{N}$-fixation.

\subsection{What sets the N:P threshold for $\mathrm{N}$-fixation?}

In Redfield's (1958) mechanism the N:P level triggering N-fixation cannot be decoupled from the $N: P$ ratio of the phytoplankton because the latter sets the threshold below which $\mathrm{N}$-fixers are selected and $\mathrm{N}$-fixation occurs. This can be explained in terms of competitive dynamics (Schade et al., 2005): If the N:P supply ratio in the water is

BGD

3, 1023-1047, 2006

Co-evolution of phytoplankton and ocean $\mathrm{N}: \mathrm{P}$ ratios

T. M. Lenton and

C. A. Klausmeier

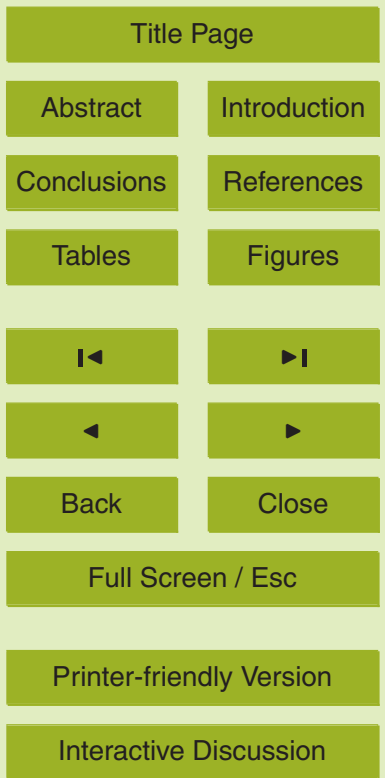

EGU 
below the $\mathrm{N}: \mathrm{P}$ requirement of non-fixers, then they will use up all the $\mathrm{N}$ and leave some $\mathrm{P}$ remaining. $\mathrm{N}$-fixers can utilise this $\mathrm{P}$ and in so doing add fixed $\mathrm{N}$ to the system. This will continue until the $N: P$ supply ratio approaches the $N: P$ requirement of the non-fixers, at which point the $\mathrm{N}$-fixers tend to be out-competed because $\mathrm{N}$-fixation is 5 an energy demanding process.

If we impose the condition that $r_{\mathrm{N}: \mathrm{P}, \mathrm{Fix}}=r_{\mathrm{C}: \mathrm{P}} / r_{\mathrm{C}: \mathrm{N}}=r_{N: P}$ in the $\mathrm{LW}$ model, then $\mathrm{NO}_{3}=226 / r_{\mathrm{C}: \mathrm{N}}$ and is always limiting, $\mathrm{PO}_{4}=226 / r_{\mathrm{C}: \mathrm{P}}+k_{P}$, hence the deep ocean $\mathrm{N}: \mathrm{P}$ ratio is:

$\frac{\mathrm{NO}_{3}}{\mathrm{PO}_{4}}=r_{\mathrm{N}: \mathrm{P}}\left(\frac{1}{1+r_{\mathrm{C}: \mathrm{P}} k_{\mathrm{P}} / 226}\right)$

10 In the original TT model, competition between $\mathrm{N}$-fixers and non-fixers is explicit and they have identical N:P ratios $\left(r_{\mathrm{N}: \mathrm{P}}=R_{O}=R_{N F}\right.$, which was $R_{\mathrm{ORG}}$ in TT's notation). Nfixers are given a lower maximum growth rate on $P$ because of the energy demands of $\mathrm{N}$-fixation. For the default parameter settings including a fixed weathering flux of $\mathrm{P}$ to the ocean, deep ocean $\mathrm{PO}_{4}=1.75 \mu \mathrm{mol} \mathrm{kg}^{-1}$ and the deep ocean $\mathrm{N}: \mathrm{P}$ ratio is given by:

${ }_{15} \frac{\mathrm{NO}_{3}}{\mathrm{PO}_{4}}=\frac{\left(r_{\mathrm{N}: \mathrm{P}} \times 1.475\right)+2}{1.75}$

Hence in both models, deep ocean $\mathrm{N}: \mathrm{P}$ tracks change in the phytoplankton $\mathrm{N}: \mathrm{P}$ ratio $\left(r_{\mathrm{N}: \mathrm{P}}\right)$, dropping further below it the more the Redfield ratio is increased. In the TT model, deep ocean $\mathrm{PO}_{4}$ is fixed, which is equivalent to fixing the C:P Redfield ratio in the LW model. In both cases, deep ocean N:P linearly tracks the phytoplankton N:P ratio entirely through changes in $\mathrm{NO}_{3}$. The only difference between the models is in the default gradient (0.84 in TT, 0.88 in LW) and offset (1.14 in TT, 0 in LW) of the relationship.

Contrary to Redfield (1958) (as quoted in Sect. 1), it is the N:P ratio of non-fixers (rather than $\mathrm{N}$-fixers) that sets the $\mathrm{N}: \mathrm{P}$ threshold for $\mathrm{N}$-fixation. Hence although $\mathrm{N}$-fixers often have a higher N:P ratio than non-fixers (Klausmeier et al., 2004) with reported

BGD

3, 1023-1047, 2006

Co-evolution of phytoplankton and ocean $\mathrm{N}$ : $\mathrm{P}$ ratios

T. M. Lenton and C. A. Klausmeier

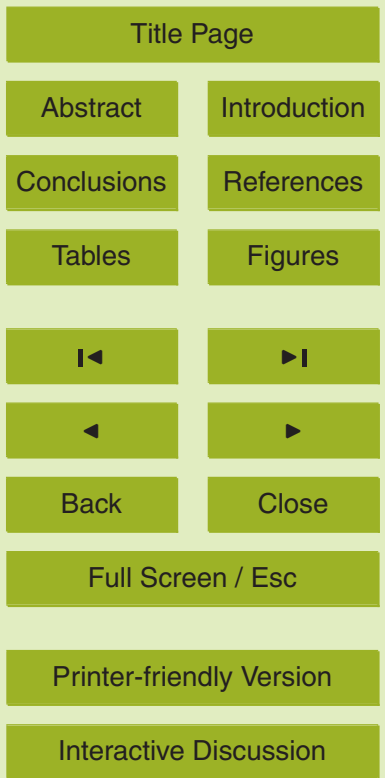

EGU 
$\mathrm{N}: \mathrm{P}$ values for $\mathrm{N}$-fixing Trichodesmium colonies ranging from 18.3 (Sañudo-Wilhelmy et al., 2001) to 125 (Karl et al., 1992), this should have little effect on the N:P of deep water, because their density is regulated by the $N: P$ requirements of the non-fixers. Our extension of the TT model to include different $N: P$ ratios for the different functional 5 groups confirms this: steady-state deep water $\mathrm{N}: \mathrm{P}$ ratio is 14.6 when $\mathrm{N}$-fixers have an $\mathrm{N}: \mathrm{P}$ ratio of 16 and 14.7 when $\mathrm{N}$-fixers have an N:P ratio of 125.

\subsection{What if the Redfield ratios vary?}

Theoretical limits on the N:P requirements of phytoplankton of 8.2-45.0 have been established (Klausmeier et al., 2004). Exponential growth favours greater allocation 10 to P-rich assembly machinery and hence a lower N:P ratio. Competitive equilibrium favours greater allocation to $\mathrm{P}$-poor resource-acquisition machinery and hence a higher $\mathrm{N}: \mathrm{P}$ ratio. Whether light, $\mathrm{N}$, or $\mathrm{P}$ is limiting has a second-order effect, with $\mathrm{P}$-limitation favouring the least allocation to assembly and the highest $N: P$ ratio.

Corresponding limits on deep ocean N:P can be derived for the TT model and for 15 the LW model with either fixed $r_{\mathrm{C}: \mathrm{P}}$ or fixed $r_{\mathrm{C}: \mathrm{N}}$ (Table 1). All three model variants give similar results. Fixed $r_{\mathrm{C}: \mathrm{N}}$ in the LW model is the most defendable, because existing data indicate that phytoplankton $\mathrm{C}: \mathrm{N}$ is less variable than N:P and C:P (Geider and La Roche, 2002; Quigg et al., 2003). This model variant suggests that deep ocean N:P has a maximum range of 7.7-32.3 (i.e. about a factor of 2 in either direction).

20 We can also use the LW model to consider the effect on ocean composition of systematic changes in the phytoplankton C:N:P over evolutionary time (Quigg et al., 2003). Table 2 shows the predicted ocean composition if it were dominated by each of a series of phyla/super-families of decreasing antiquity. This indicates that a general decrease in $\mathrm{N}: \mathrm{P}$ ratios of marine phytoplankton over the past $\sim 1 \mathrm{Gyr}$ would have tended to decrease deep ocean N:P. This is predicted to have occurred via increasing ocean $\mathrm{PO}_{4}$, due to the general decrease in phytoplankton C:P, whereas the relative constancy of the phytoplankton $\mathrm{C}: \mathrm{N}$ ratio would not have forced $\mathrm{NO}_{3}$.

BGD

3, 1023-1047, 2006

Co-evolution of phytoplankton and ocean N:P ratios

T. M. Lenton and

C. A. Klausmeier

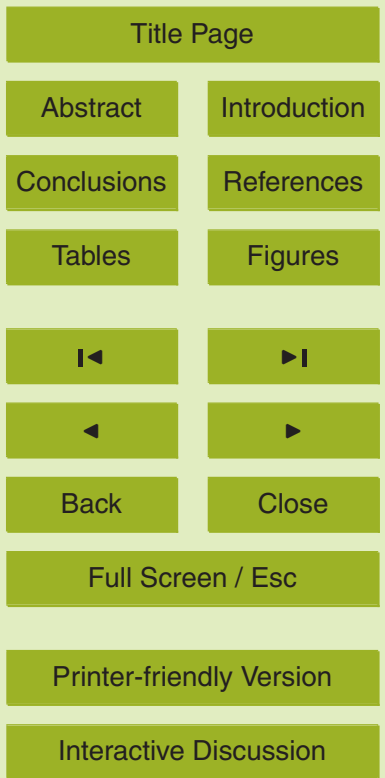

EGU 


\subsection{What if phosphorus weathering also varies?}

The above inferences assume weathering forcing $(W)$ is fixed, which has not been the case (Bergman et al., 2004; Lenton and Watson, 2004). The biological colonisation of the land surface has tended to accelerate weathering, in particular of phospho5 rus. Retaining the dependence on weathering forcing in the LW model but assuming $r_{N: P, F i X}=r_{\mathrm{N}: \mathrm{P}}$ gives:

$\frac{\mathrm{NO}_{3}}{\mathrm{PO}_{4}}=r_{\mathrm{N}: \mathrm{P}}\left(1-\frac{4.025-3.025 W}{1+226 / r_{\mathrm{C}: \mathrm{P}} k_{\mathrm{P}}}\right)$

Thus a general increase in weathering forcing $(W)$ toward the present, due to biotic colonisation of the land surface would have tended to increase deep ocean N:P, bringing it closer to the $\mathrm{N}: \mathrm{P}$ of the phytoplankton. This may have counteracted a decline in deep ocean N:P driven by a declining N:P Redfield ratio. An order of magnitude increase in $W$ from 0.1 to 1 over the past $\sim 1000$ Myr is probably an upper limit, and for $r_{\mathrm{C}: \mathrm{P}}=117$ as at present, this raises deep ocean N:P from $\sim 55 \%$ to $\sim 88 \%$ of the Redfield ratio. A factor of two increase in $W$ is more reasonable and $W=0.5$ gives deep ocean $\mathrm{N}: \mathrm{P} \sim 69 \%$ of the Redfield ratio.

In contrast, 1000 Myr ago the N:P Redfield ratio could have been $\sim 29$ (averaging the values for Prasinophyceae and Chlorophyceae in Table 2; Quigg et al., 2003). This suggests a decline in the N:P Redfield ratio could have dominated over an increase in weathering and generated an overall decline in deep ocean $\mathrm{N}: \mathrm{P}$. Lowering weathering ferred overall increase in deep ocean N:P over the past $~ 1000$ Myr could have involved an increase in $\mathrm{NO}_{3}$ (driven indirectly by increasing weathering) as well as a proportionally larger increase in $\mathrm{PO}_{4}$ (driven primarily by declining $\mathrm{N}: \mathrm{P}$ of phytoplankton).

BGD

3, 1023-1047, 2006

Co-evolution of phytoplankton and ocean $\mathrm{N}: \mathrm{P}$ ratios

T. M. Lenton and

C. A. Klausmeier

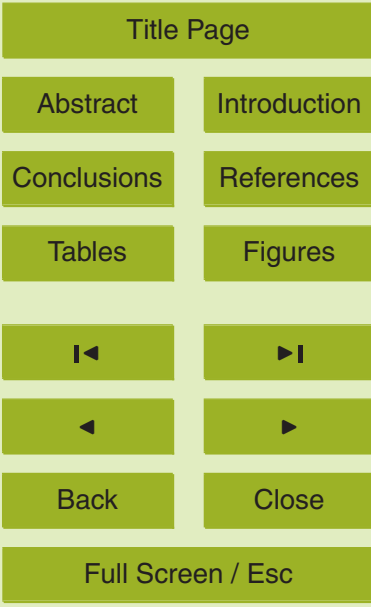

Printer-friendly Version

Interactive Discussion 
Having explored how variation in the Redfield ratios and phosphorus weathering could have altered deep ocean $\mathrm{N}: \mathrm{P}$, we finish by considering the potential impact of limitations on $\mathrm{N}$-fixation. We find that deep ocean $\mathrm{N}: \mathrm{P}$ is remarkably well regulated as $\mathrm{N}$-fixation 5 is restricted to a progressively smaller fraction $\left(f_{A}\right)$ of the surface ocean (Fig. 1). As $f_{A}$ is reduced from 1 to 0.33 , steady state deep ocean $\mathrm{N}: \mathrm{P}$ declines from 14.6 to 11.5 , for example, when only $50 \%$ of the ocean is available to $\mathrm{N}$-fixers, deep N:P is 12.9. As $f_{A}$ is reduced below 0.33 , the system undergoes a Hopf bifurcation to an oscillating solution, and deep N:P actually increases, oscillating in the range 13.5-13.7 for $f_{A}=0.329$. As $f_{A}$

10 is reduced further, deep N:P declines in a non-linear fashion, for example, when only $25 \%$ of the ocean is available to N-fixers, the deep N:P oscillates in the range 12.813.0 , whereas when $\mathrm{N}$-fixers are restricted to $15 \%$ of the surface ocean, deep N:P is still 11.5-11.7. As $f_{A}$ tends to zero, deep ocean N:P also tends to zero, and in the absence of $\mathrm{N}$-fixers, the oscillations disappear.

Such homeostatic biotic control over whole ocean stoichiometry is maintained because $\mathrm{N}$-fixers reach higher densities when restricted to smaller fractions of the ocean's surface, compensating for their reduced distribution. Although the predicted values of deep N:P fall below those observed, this is sensitive to the choice of model parameters. If we assume that the $\mathrm{N}: \mathrm{P}$ Redfield ratio of non-fixers $\left(R_{O}\right)$ is somewhat greater than 16 , this can compensate for restricting $\mathrm{N}$-fixers to a fraction of the ocean's surface, for example, with $f_{A}=0.5, R_{O}=18$ recovers a deep ocean $\mathrm{N}: \mathrm{P}=14.3$.

\section{Discussion}

Existing explanations of the correspondence between phytoplankton N:P and deep ocean N:P have often included the tenets that: (1) C:N:P $=106: 16: 1$ represents a biochemical optimum for the phytoplankton, (2) N:P of sinking material sets deep ocean $\mathrm{N}: \mathrm{P},(3) \mathrm{N}$-fixation occurs when up-welled $\mathrm{N}: \mathrm{P}<16$. These points have all been chal-

\section{BGD}

3, 1023-1047, 2006

Co-evolution of phytoplankton and ocean $\mathrm{N}: \mathrm{P}$ ratios

T. M. Lenton and

C. A. Klausmeier

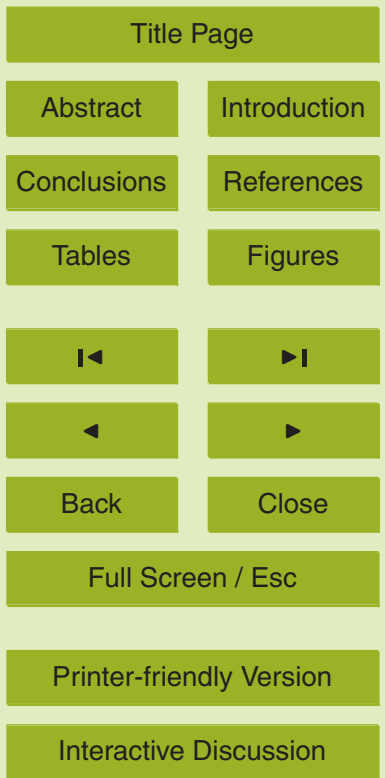

EGU 
lenged here and elsewhere and are revised as follows: (1) As Redfield recognised, phytoplankton $\mathrm{C}: \mathrm{N}: \mathrm{P}=106: 16: 1$ simply represents an average of the present phytoplankton community, there is as yet no evidence that it is optimal, and $\mathrm{C}: \mathrm{N}: \mathrm{P}$ is now known to vary with growth conditions, among species, and (probably) over evolution-

5 ary time. (2) The N:P ratio that triggers $N$-fixation sets the $N: P$ ratio of the deep ocean (referring here to the average concentrations of $\mathrm{N}$ and $\mathrm{P}$, not the proportions in which they are remineralised), which is not directly related to the $N: P$ ratio of sinking material (or any other process that merely redistributes $N$ and $P$ within the ocean). (3) The N:P uptake ratio of other plankton determines the N:P threshold for $\mathrm{N}$-fixation, and 10 hence indirectly sets deep ocean N:P. Furthermore, N-fixation can be limited by Fe, light or other factors, such that $\mathrm{N}$-fixers are restricted to a modest fraction of the surface ocean, but they can still maintain deep ocean $N: P$ relatively close to the $N: P$ of other phytoplankton.

The other side of Redfield's mechanism is that denitrification somewhat lowers deep ocean $\mathrm{N}: \mathrm{P}$, thus maintaining a population of $\mathrm{N}$-fixers. This needs elaborating given the recent discoveries that anaerobic ammonium oxidation ("anammox"; $\mathrm{NH}_{4}^{+}+\mathrm{NO}_{2}^{-} \rightarrow \mathrm{N}_{2}+2 \mathrm{H}_{2} \mathrm{O}$ ) in the ocean water column and sediments, is responsible for significant removal (up to 30-50\%) of fixed nitrogen (Dalsgaard et al., 2003; Kuypers et al., 2003). Anammox may thus contribute to lowering deep ocean N:P. However, the nitrite $\left(\mathrm{NO}_{2}^{-}\right)$used in the anammox reaction at depth appears to be supplied by denitrification (of $\mathrm{NO}_{3}$ ), and both processes occur under anaerobic conditions. Hence there is no qualitative change to the overall negative feedback between the amount of available $\mathrm{N}$ in the ocean and its removal. For example, an increase in fixed $\mathrm{N}$ will lead to an increase in new production in $\mathrm{N}$ limited regions, which will promote anoxia at depth, tending to increase denitrification and anammox, both of which remove fixed N.

An additional mechanism not modelled herein is that phosphorite formation and consequent $\mathrm{P}$ removal from the ocean can be associated with fixed $\mathrm{N}$ removal (Piper and Codispoti, 1975; Schulz and Schulz, 2005). Qualitatively this acts in the right direction

\section{BGD}

3, 1023-1047, 2006

\section{Co-evolution of phytoplankton and ocean N:P ratios}

T. M. Lenton and

C. A. Klausmeier

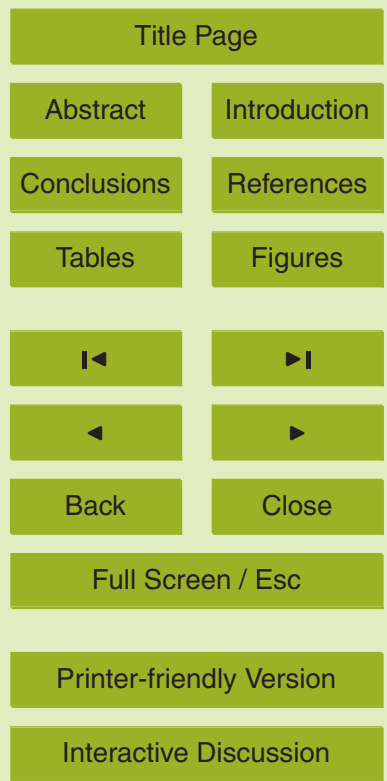


to stabilise the deep ocean $\mathrm{N}: \mathrm{P}$ ratio, although its effect will clearly depend on the (as yet unknown) proportions in which $\mathrm{N}$ and $\mathrm{P}$ are removed.

Our model based analysis suggests that long-term changes in the average phytoplankton $\mathrm{N}: \mathrm{P}$ Redfield ratio can drive changes in deep ocean $\mathrm{N}: \mathrm{P}$, on timescales longer 5 than the $\sim 10^{4}$ year residence time of $\mathrm{PO}_{4}$. The greater variability in $\mathrm{C}: \mathrm{P}$ than $\mathrm{C}: \mathrm{N}$ Redfield ratios implies that such stoichiometrically driven changes in deep ocean N:P occur primarily through changes in $\mathrm{PO}_{4}$. Hence a suggested decline in $\mathrm{N}: \mathrm{P}$ and $\mathrm{C}: \mathrm{P}$ Redfield ratios over evolutionary time (Quigg et al., 2003) implies a corresponding decline in the deep ocean $\mathrm{N}: \mathrm{P}$ ratio, occurring via an increase in $\mathrm{PO}_{4}$.

10 The lower $\mathrm{PO}_{4}$ we predict in the mid-Proterozoic 1200-1000 Ma (Table 2) is consistent with much lower $\mathrm{PO}_{4}$ in the early Proterozoic $1900 \mathrm{Ma}$, followed by a rise in $\mathrm{PO}_{4}$ due to less removal on iron oxides (Bjerrum and Canfield, 2002). A further rise in $\mathrm{PO}_{4}$ over the last $\sim 1000 \mathrm{Myr}$ is consistent with an increase in phosphorus weathering flux from the continents due to the biological colonisation of the land surface. Land colonisation may have been stepwise, with one burst in the Neoproterozoic, perhaps involving the first lichens (Lenton and Watson, 2004; Yuan et al., 2005), and a second in the early Phanerozoic with the rise of vascular land plants (Lenton, 2001). Corresponding increases in atmospheric oxygen (Lenton, 2001; Lenton and Watson, 2004) would have suppressed anoxia and denitrification (plus anammox) thus increasing $\mathrm{NO}_{3}$ and bringing deep ocean N:P closer toward whatever was the average phytoplankton $\mathrm{N}: \mathrm{P}$ at the time.

In this scenario, the higher $\mathrm{N}: \mathrm{P}$ ratios of older phyla/super-families do not reflect adaptation to external drivers of ocean composition, because although phosphorus input was probably lower when they arose, so was atmospheric oxygen, making denitrification (and anammox) more extensive and leading to a lower predicted deep ocean $\mathrm{N}: \mathrm{P}$. We suggest that the evolution of the composition of the organisms drove ocean composition rather than vice versa. This extends Redfield's (1958) argument for the present ocean by adding an evolutionary time dimension. We describe our scenario as "co-evolution" of phytoplankton C:N:P stoichiometry and deep ocean N:P because the

\section{BGD}

3, 1023-1047, 2006

\section{Co-evolution of phytoplankton and ocean $\mathrm{N}: \mathrm{P}$ ratios}

T. M. Lenton and

C. A. Klausmeier

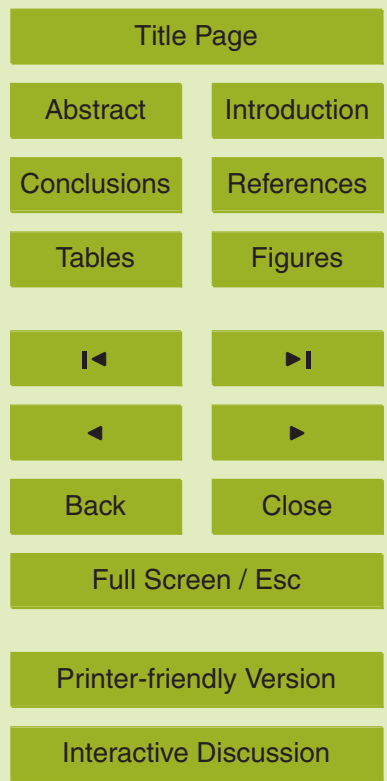


composition of the environment is predicted to track evolutionary changes in the composition of the organisms. The question then becomes; what is driving the evolution of phytoplankton composition?

To make further progress we suggest that a model of competing populations with 5 differing stoichiometry could be nested within a model of ocean composition subject to external drivers. The populations themselves could exhibit phenotypic plasticity in their stoichiometry as their resource allocation varies in response to prevailing conditions (Klausmeier et al., 2004). However, acknowledging that phytoplankton composition may adapt (within limits) to the composition of the ocean, as well as alter it, will make 10 disentangling cause and effect even more difficult. Circular reasoning is a common problem in any feedback system with closed loops of cause and effect, and we have struggled to avoid it here. We suspect that the real system is even more complex than we have envisaged.

\section{Extensions to the carbon cycle}

15 Our argument that changes in phytoplankton composition drive changes in ocean composition has interesting potential extensions to the carbon cycle. On short timescales, an increase in $\mathrm{C}: \mathrm{N}$ and $\mathrm{C}: \mathrm{P}$ Redfield ratios will give rise to increased carbon export from the surface ocean (new production). However, our modelling suggests that on timescales longer than their residence times, the ocean $\mathrm{NO}_{3}$ and $\mathrm{PO}_{4}$ reservoirs ad20 just such that new production tends to be fairly constant. This is consistent with the stability of the $\delta^{13} \mathrm{C}$ record (Schidlowski, 1988).

In one of many hypotheses to explain the lower $\mathrm{CO}_{2}$ at the Last Glacial Maximum, Broecker and Henderson (1998) suggest that a 50\% increase in plankton N:P and deep ocean $\mathrm{N}$ (with the same plankton $\mathrm{C}: \mathrm{N}$ ) could drive the requisite increase in the organic carbon pump. Such an increase in plankton N:P demands a shift from "reds" to "greens" (Quigg et al., 2003) and/or a more nutrient or light limited regime in the surface ocean (Klausmeier et al., 2004). More importantly, the models we have examined
BGD

3, 1023-1047, 2006

Co-evolution of phytoplankton and ocean $\mathrm{N}: \mathrm{P}$ ratios

T. M. Lenton and

C. A. Klausmeier

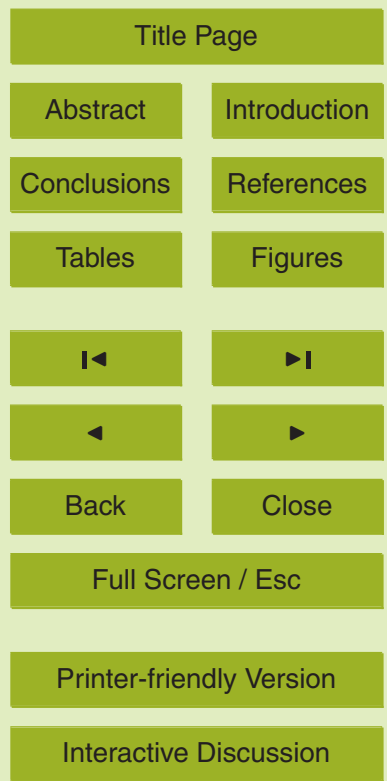

EGU 
suggest deep ocean $\mathrm{N}$, and new production are self-regulated. A $50 \%$ increase in phytoplankton N:P does not in itself drive an increase in deep ocean $\mathrm{N}$ (e.g. Table 2).

Indeed a $50 \%$ increase in deep ocean $\mathrm{N}$ and carbon export can only occur with a similar increase in weathering input of $P$ to the ocean.

5 The potential effects of $\mathrm{CO}_{2}$ on phytoplankton composition are of interest for both the glacial world of lower $\mathrm{CO}_{2}$ and the present and future world of increasing $\mathrm{CO}_{2}$. Increases in $\mathrm{C}: \mathrm{N}$ and $\mathrm{C}: \mathrm{P}$ with increasing $\mathrm{CO}_{2}$ have been seen in a naked strain of Emiliania huxleyi (Leonardos and Geider, 2005). Increases in C:N and inorganic carbon drawdown also occur under elevated $\mathrm{CO}_{2}$ in mesocosm experiments (Riebesell, 10 et al., 2006). This suggests a potential negative feedback in which increasing $\mathrm{CO}_{2}$ generates an enhanced organic carbon pump and vice versa. This only adds to the difficulty of explaining lower glacial $\mathrm{CO}_{2}$ levels.

\section{Conclusion}

Despite potential variability in phytoplankton stoichiometry, weathering supply of phos15 phorus to the ocean, and widespread $\mathrm{Fe}$ and/or light limitation of $\mathrm{N}$-fixation, we find that Redfield's mechanism can still regulate deep ocean N:P somewhat below the proportions that trigger $\mathrm{N}$-fixation in those areas of the ocean where it is limited by $\mathrm{P}$ and suppressed by $\mathrm{N}$ addition. Furthermore, deep ocean $\mathrm{N}: \mathrm{P}$ is unlikely to have varied by more than a factor of two in either direction since the deep oceans became well oxygenated. We extend Redfield's mechanism to suggest that within these bounds, the evolution of phytoplankton composition drove long-term changes in ocean composition. Decreases in phytoplankton $\mathrm{C}: \mathrm{P}$ and $\mathrm{N}: \mathrm{P}$ ratios over the past $\sim 1 \mathrm{Gyr}$ are predicted to have driven a decrease in deep ocean $\mathrm{N}: \mathrm{P}$, via increasing $\mathrm{PO}_{4}$.

Acknowledgements. We thank J. Elser and D. Hessen for organizing the workshop that trig25 gered this work. T. M. Lenton thanks the European Geosciences Union for an Outstanding Young Scientist Award 2006 and the resulting invitation to contribute this paper.

\section{Co-evolution of phytoplankton and ocean $\mathrm{N}: \mathrm{P}$ ratios}

T. M. Lenton and

C. A. Klausmeier

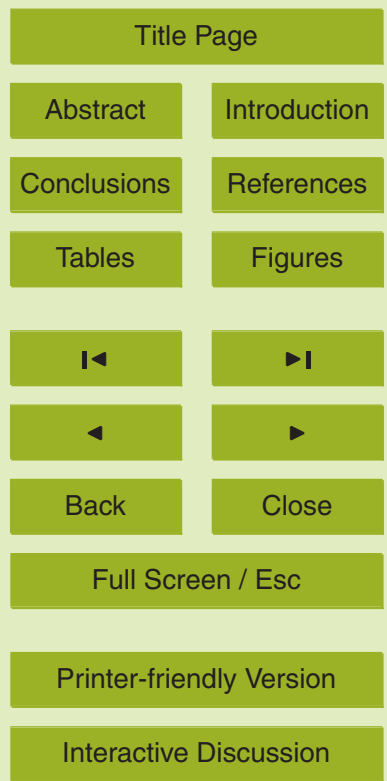




\section{References}

Anderson, L. A. and Sarmiento, J. L.: Redfield ratios of remineralization determined by nutrient data analysis, Glob. Biogeochem. Cycl., 8, 65-80, 1994.

Arrigo, K. R.: Marine microorganisms and global nutrient cycles, Nature, 437, 349-355, 2005.

5 Bergman, N. M., Lenton, T. M., and Watson, A. J.: COPSE: a new model of biogeochemical cycling over Phanerozoic time, American Journal of Science, 304, 397-437, 2004.

Berman-Frank, I., Cullen, J. T., Shaked, Y., Sherrell, R. M., and Falkowski, P. G.: Iron availability, cellular iron quotas, and nitrogen fixation in Trichodesmium, Limnol. Oceanogr., 46, 12491260, 2001.

10 Bjerrum, C. J. and Canfield, D. E.: Ocean productivity before about 1.9 Gyr ago limited by phosphorus adsorption onto iron oxides, Nature, 417, 159-162, 2002.

Broecker, W. S. and Henderson, G. M.: The sequence of events surrounding Termination II and their implications for the cause of glacial-interglacial CO2 changes, Paleoceanography, 13, 352-364, 1998.

15 Broecker, W. S. and Peng, T.-H.: Tracers in the Sea, Eldigio Press, New York, 1982.

Codispoti, L. A.: Is the ocean losing nitrate?, Nature, 376, 724, 1995.

Dalsgaard, T., Canfield, D. E., Petersen, J., Thamdrup, B., and Acuna-Gonzalez, J.: N2 production by the anammox reaction in the anoxic water of Golfo Dulce, Costa Rica, Nature, 422, 606-608, 2003.

20 Falkowski, P. G. and Davis, C. S.: Natural proportions, Nature, 431, 131, 2004.

Geider, R. J. and La Roche, J.: Redfield revisited: variability of C:N:P in marine microalgae and its biochemical basis, Eur. J. Phycol., 37, 1-17, 2002.

Goldman, J. C.: On phytoplankton growth rates and particulate C:N:P ratios at low light, Limnol. Oceanogr., 31, 1358-1361, 1986.

Goldman, J. C., McCarthy, J. J., and Peavey, D. G.: Growth rate influence on the chemical composition of phytoplankton in oceanic waters, Nature, 279, 210-215, 1979.

Hood, R. R., Coles, V. J., and Capone, D. G.: Modeling the distribution of Trichodesmium and nitrogen fixation in the Atlantic Ocean, J. Geophys. Res., 109, 1-25, 2004.

Karl, D. M., Letelier, R., Hebel, D. V., Bird, D. F., and Winn, C. D.: Trichodesmium blooms and new nitrogen in the North Pacific Gyre, in: Marine Pelagic Cyanobacteria: Trichodesmium and Other Diazotrophs, edited by: Carpenter, E. J., Kluwer Academic Publishers, pp. 219237, 1992.
BGD

3, 1023-1047, 2006

Co-evolution of phytoplankton and ocean N:P ratios

T. M. Lenton and

C. A. Klausmeier

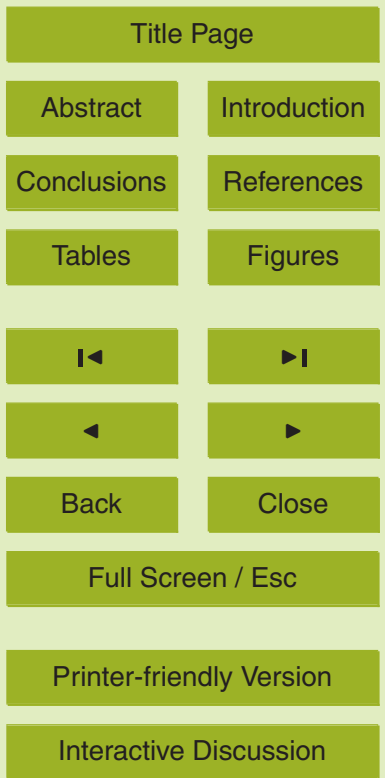


Klausmeier, C. A., Litchman, E., Daufresne, T., and Levin, S. A.: Optimal nitrogen-tophosphorus stoichiometry of phytoplankton, Nature, 429, 171-174, 2004.

Kuypers, M. M. M., Sliekers, A. O., Lavik, G., Schmid, M., Jorgensen, B. B., Kuenen, J. G., Sinninghe Damste, J. S., Strous, M., and Jetten, M. S. M.: Anaerobic ammonium oxidation by anammox bacteria in the Black Sea, Nature, 422, 608-611, 2003.

Lenton, T. M.: The role of land plants, phosphorus weathering and fire in the rise and regulation of atmospheric oxygen, Global Change Biol., 7, 613-629, 2001.

Lenton, T. M. and Watson, A. J.: Redfield revisited: 1. Regulation of nitrate, phosphate and oxygen in the ocean, Glob. Biogeochem. Cycl., 14, 225-248, 2000.

10 Lenton, T. M. and Watson, A. J.: Biotic enhancement of weathering, atmospheric oxygen and carbon dioxide in the Neoproterozoic, Geophys. Res. Lett., 31, L05202, doi:10.1029/2003GL018802, 2004.

Leonardos, N. and Geider, R. J.: Elevated atmospheric carbon dioxide increases organic carbon fixation by Emiliania huxleyi (Haptophyta) under nutrient-limited high-light conditions, J.

15 Phycol., 41, 1196-1203, 2005.

Mills, M. M., Ridame, C., Davey, M., La Roche, J., and Geider, R. J.: Iron and phosphorus co-limit nitrogen fixation in the eastern tropical North Atlantic, Nature, 429, 292-294, 2004.

Piper, D. Z. and Codispoti, L. A.: Marine Phosphorite Deposits and the Nitrogen Cycle, Science, 188, 15-18, 1975.

20 Quigg, A., Finkel, Z. V., Irwin, A. J., Rosenthal, Y., Ho, T.-Y., Reinfelder, J. R., Schofield, O., Morel, F. M. M., and Falkowski, P. G.: The evolutionary inheritance of elemental stoichiometry in marine phytoplankton, Nature, 425, 291-294, 2003.

Redfield, A. C.: On the proportions of organic derivatives in sea water and their relation to the composition of plankton, James Johnstone Memorial Volume, University of Liverpool,

25 Liverpool, pp. 176-192, 1934.

Redfield, A. C.: The biological control of chemical factors in the environment, Am. Sci., 46, 205-221, 1958.

Riebesell, U., Schulz, K., and the PeECEIII participants: Pelagic Ecosystem CO2 Enrichment (PeECE III) Study: A glimpse at the future ocean, Geophys. Res. Abstr., 8, 08149, 2006.

30 Ruttenberg, K. C.: Reassessment of the oceanic residence time of phosphorus, Chem. Geol., 107, 405-409, 1993.

Sañudo-Wilhelmy, S. A., Kustka, A. B., Gobler, C. J., Hutchins, D. A., Yang, M., Lwiza, K., Burns, J., Capone, D. G., Raven, J. A., and Carpenter, E. J.: Phosphorus limitation of nitrogen

BGD

3, 1023-1047, 2006

Co-evolution of phytoplankton and ocean $\mathrm{N}: \mathrm{P}$ ratios

T. M. Lenton and

C. A. Klausmeier

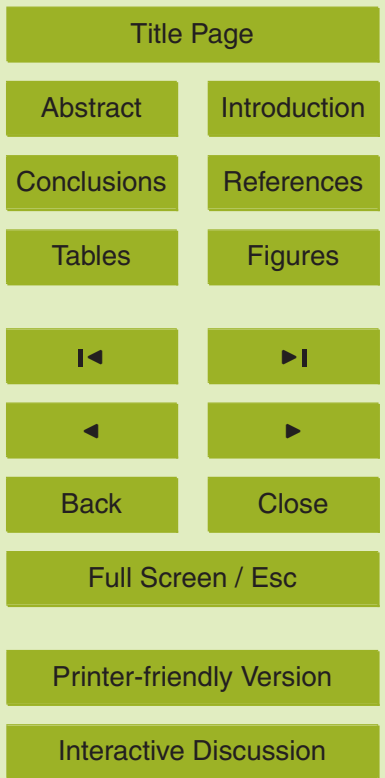

EGU 
fixation by Trichodesmium in the central Atlantic Ocean, Nature, 411, 66-69, 2001.

Schade, J. D., Espelata, J. F., Klausmeier, C. A., McGroddy, M. E., Thomas, S. A. and Zhang, L.: A conceptual framework for ecosystem stoichiometry: balancing resource supply and demand, Oikos, 109, 40-51, 2005.

5 Schidlowski, M.: A 3,800-million-year isotopic record of life from carbon in sedimentary rocks, Nature, 333, 313-318, 1988.

Schulz, H. N. and Schulz, H. D.: Large Sulfur Bacteria and the Formation of Phosphorite, Science, 307, 416-418, 2005.

Tyrrell, T.: The relative influences of nitrogen and phosphorus on oceanic primary production, Nature, 400, 525-531, 1999.

Yuan, X., Xiao, S., and Taylor, T. N.: Lichen-Like Symbiosis 600 Million Years Ago, Science, 308, 1017-1020, 2005.

\section{BGD}

3, 1023-1047, 2006

Co-evolution of phytoplankton and ocean $\mathrm{N}: \mathrm{P}$ ratios

T. M. Lenton and

C. A. Klausmeier

Title Page

Abstract Introduction

Conclusions

References

Tables

Figures

14

$\rightarrow 1$

4

Back

Close

Printer-friendly Version

Interactive Discussion 
BGD

3, 1023-1047, 2006

Co-evolution of phytoplankton and ocean $\mathrm{N}$ : $\mathrm{P}$ ratios

T. M. Lenton and

C. A. Klausmeier

Table 1. Limits on ocean composition predicted from theoretical limits on
of phytoplankton (Klausmeier et al., 2004) using the TT and LW models.

\begin{tabular}{lcccc}
\hline \multirow{2}{*}{ Limit } & Phytoplankton N:P & \multicolumn{3}{c}{ Predicted N:P of deep ocean } \\
\cline { 3 - 5 } & & TT & LW with & LW with \\
& & & $r_{\mathrm{C}: \mathrm{P}}=117$ & $r_{\mathrm{C}: \mathrm{N}}=7.3$ \\
\hline Control & 16 & 14.6 & 14.0 & 14.0 \\
Exponential growth & 8.2 & 8.1 & 7.2 & 7.7 \\
Light limitation & 35.8 & 31.3 & 31.4 & 27.3 \\
N-limitation & 37.4 & 32.7 & 32.8 & 28.2 \\
P-limitation & 45.0 & 39.1 & 39.5 & 32.3 \\
\hline
\end{tabular}


BGD

3, 1023-1047, 2006

Co-evolution of phytoplankton and ocean $\mathrm{N}$ : $\mathrm{P}$ ratios

Table 2. Expected ocean composition if dominated by various phyla of phytoplankton. Predicted from the Redfield ratios found by (Quigg et al., 2003) and the adapted LW model, assuming the N:P Redfield ratio is the threshold below which $\mathrm{N}$-fixation occurs.

\begin{tabular}{lcccc}
\hline $\begin{array}{l}\text { Phylum/superfamily } \\
\text { (and age) }\end{array}$ & C:N:P ratio & $\begin{array}{c}\mathrm{NO}_{3} \\
\left(\mu \mathrm{mol} \mathrm{kg}^{-1}\right)\end{array}$ & $\begin{array}{c}\mathrm{PO}_{4} \\
\left(\mu \mathrm{mol} \mathrm{kg}^{-1}\right)\end{array}$ & $\mathrm{NO}_{3}: \mathrm{PO}_{4}$ \\
\hline $\begin{array}{l}\text { Prasinophyceae } \\
\text { (1200 Myr) }\end{array}$ & $200: 25: 1$ & 28 & 1.4 & 20 \\
$\begin{array}{l}\text { Chlorophyceae } \\
\text { (1000 Myr) }\end{array}$ & $200: 33: 1$ & 38 & 1.4 & 27 \\
$\begin{array}{l}\text { Dinophyceae } \\
\text { (440 Myr) }\end{array}$ & $140: 13: 1$ & 21 & 1.9 & 11 \\
$\begin{array}{l}\text { Prymnesiophyceae } \\
(210 \text { Myr })\end{array}$ & $60: 9: 1$ & 32 & 4.0 & 8.0 \\
$\begin{array}{l}\text { Diatoms } \\
(<200 \mathrm{Myr})\end{array}$ & $70: 10: 1$ & 32 & 3.5 & 9.2 \\
\hline
\end{tabular}

T. M. Lenton and

C. A. Klausmeier

Title Page

Abstract

Introduction

Conclusions

References

Tables

Figures

14

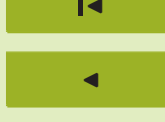

Back

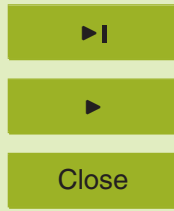

Full Screen / Esc

Printer-friendly Version

Interactive Discussion 


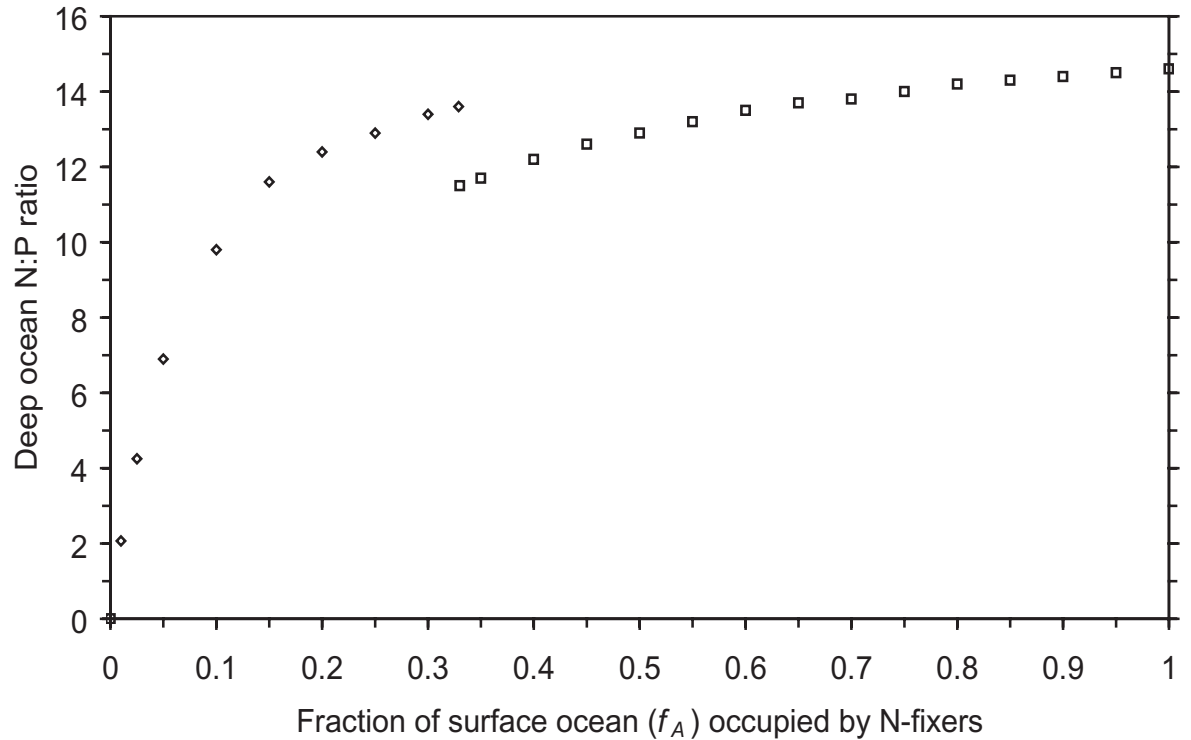

Fig. 1. Dependence of the steady state deep ocean N:P ratio on the fraction of the surface ocean occupied by N-fixers $\left(f_{A}\right)$. Predicted by the extended TT model assuming an N:P Redfield ratio of 16 for both $\mathrm{N}$-fixers and other phytoplankton. Squares symbols indicate a stable solution, diamond symbols a limit cycle (oscillating solution). The oscillations are small, with a maximum amplitude of $\sim 0.75 \%$ (e.g. $13.3-13.5$ for $f_{A}=0.3$ ), and the diamonds are plotted at the mid point of the oscillations. The transition from a stable steady state to a limit cycle occurs in the range $f_{A}=0.329-0.330$.
3, 1023-1047, 2006

Co-evolution of phytoplankton and ocean $\mathrm{N}$ : $\mathrm{P}$ ratios

T. M. Lenton and

C. A. Klausmeier

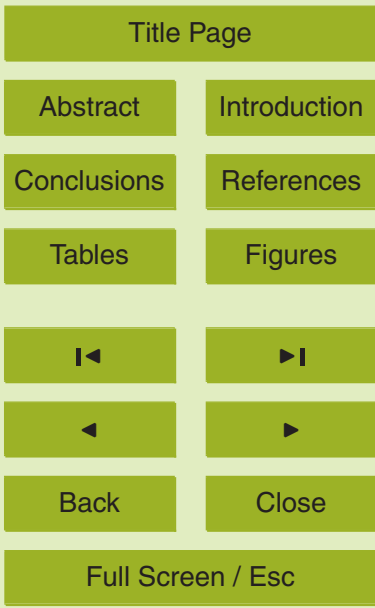

Printer-friendly Version

Interactive Discussion 